\title{
HUBUNGAN VOLUME TEGAKAN DENGAN KANDUNGAN BIOMASSA TERSIMPAN SKALA PLOT PADA AREAL AGROFORESTRY DUSUNG DI DUSUN TOISAPU KOTA AMBON
}

\author{
RELATIONSHIP OF VOLUME OF STRESS WITH STORED SCOT BIOMASS CONTENT \\ IN THE AGROFORESTRY AREA SUPPOSED IN THE TOISAPU DUSUN, AMBON CITY
}

\author{
Alvanolis Ivanno Passal ${ }^{1}$, Gun Mardiatmoko ${ }^{2)}$ dan Fransina Latumahina ${ }^{3)}$ \\ ${ }^{1}$ Mahasiswa Pascasarjana Program Studi Managemen Hutan Universitas Pattimura Ambon \\ ${ }^{23}$ Dosen Pascasarjana Program Studi Managemen Hutan Universitas Pattimura Ambon
}

Email: ivanpassal19@gmail.com

\begin{tabular}{l|l} 
Diterima : 16 Desember 2018 & Disetujui : 5 Februari 2019
\end{tabular}

\begin{abstract}
Abstrak
Penelitian dilaksanakan pada areal Hutan Rakyat (Agroforestry) Dusung di Dusun Toisapu Negeri Hutumuri Kecamatan Leitimur Selatan Kota Ambon pada Bulan Agustus - Oktober 2018 untuk menentukan hubungan antara volume tegakan dan kandungan biomasa tersimpan untuk skala plot pada areal agroforestry dusung di Dusun Toisapu. Untuk itu, diawali dengan menginventarisasi potensi pada tingkat semai, pancang, tiang dan pohon sehingga diperolehnya informasi dan data potensi aktual kandungan karbon pada sistem dusung berdasarkan nilai keragaman volume tegakan dan nilai kandungan biomassa. Hasil penelitian pada tiga plot pengukuran menunjukan bahwa biomasa tertinggi terlihat didominasi oleh jenis tanaman Durian, Pala dan tanaman Langsat serta Duku dan Cengkih. Berdasarkan perhitungan nilai biomassa terhadap jumlah kandungan karbon pada ketiga plot, terlihat potensi biomassa untuk total luas petak ukur $400 \mathrm{~m}^{2}$ atau 0,04 ha untuk ketiga plot dengan seluas $1.200 \mathrm{~m}^{2}$ atau 0,12 ha memiliki jumlah total biomassa $50.783,77 \mathrm{Kg} / \mathrm{m}^{2}$ yang dikalikan dengan asumsi $0,5 \%$ dari total jumlah biomassa pohon dan tiang sehingga jumlah kandungan karbon yang tersimpan pada ketiga plot sebesar $25.391,88 \mathrm{~kg} / \mathrm{m}^{2}$ atau $2.539,19$ ton/ha.
\end{abstract}

Kata Kunci : Agroforestry, Biomassa Dusung.

\begin{abstract}
The study was carried out in the Dusung Community Forest (Agroforestry) area of Toisapu Negeri Hutumuri Hamlet, South Leitimur Sub-District, Ambon City in August - October 2018 to determine the relationship between stand volume and stored biomass for scale plots in dusung agroforestry areas in Toisapu Hamlet. For this reason, it begins with an inventory of potential at seedling, sapling, pole and tree levels so that information and data on the actual potential of carbon content in the dusung system are obtained based on the value of the diversity of stand volume and biomass content. The results of the three measurement plots showed that the highest biomass was seen to be dominated by Durian, Pala and Langsat and Duku and Clove plants. Based on the calculation of the biomass value of the total carbon content in the three plots, it can be seen biomass potential for a total $400 \mathrm{~m}^{2}$ plot area or 0.04 ha for the three plots with an area of $1,200 \mathrm{~m}^{2}$ or 0.12 ha having a total biomass of $50,783.77 \mathrm{Kg} / \mathrm{m}^{2}$ multiplied by the assumption of $0.5 \%$ of the total amount of tree biomass and poles so that the total carbon content stored in the three plots is $25,391.88 \mathrm{~kg} / \mathrm{m}^{2}$ or $2,539.19$ tons / ha.
\end{abstract}

Keywords: Agroforestry, Shelter Biomass. 


\section{PENDAHULUAN}

Hutan mengabsorpsi $\mathrm{CO}_{2}$ selama proses fotosintesis dan menyimpannya sebagai materi organik dalam biomassa tanaman. Banyaknya materi organik yang tersimpan dalam biomassa hutan per unit luas dan per unit waktu merupakan pokok dari produktivitas hutan. Produktivitas hutan merupakan gambaran kemampuan hutan dalam mengurangi emisi $\mathrm{CO}_{2}$ di atmosfir melalui aktivitas physiologi. Pengukuran produktivitas hutan relevan dengan pengukuran biomassa. Biomassa hutan menyediakan informasi penting dalam menduga besarnya potensi penyerapan $\mathrm{CO}_{2}$ dan biomassa dalam umur tertentu yang dapat dipergunakan untuk mengestimasi produktivitas hutan (Heriyanto dan Sugiyanto, 2012).

Hutan tropik memiliki sumber cadangan karbon sangat besar yang dapat berubah akibat perubahan kondisi hutan yang disebabkan oleh aktivitas manusia, termasuk penebangan dan perkebunan sehingga mengancam perubahan iklim dunia. Kajian analisis dilakukan untuk menetahui struktur vegetasi dan kandungan karbon pada tiga kondisi hutan di Pulau Siberut sebagai upaya mitigasi perubahan iklim (Chairul dkk, 2016)

Salah satu persyaratan mengikuti mekanisme perdagangan karbon, adalah dengan menghitung potensi karbon melalui program REDD atau Reducing Emissions from Deforestation and Forest Degradation
(Pengurangan Emisi dari Deforestasi dan Degradasi Hutan) tersebut. Untuk itu perhitungan cadangan karbon dan potensi emisi dengan skenario tanpa dan dengan proyek, perlu dilakukan secara sistematis dan dipertanggungjawabkan.

Untuk penghitungan cadangan karbon, perlu dilakukan inventarisasi untuk mengukur potensi karbon dari berbagai sumber karbon (carbon pool) yang ada di hutan. Selain itu perlu juga dilakukan monitoring secara berkala dengan melakukan pengukuran pada petak ukur permanen. Kombinasi dengan pendekatan penginderaan jauh dapat membantu memudahkan proses pendugaan dan pemantauan karbon (Muhammad, 2016).

Tingginya jumlah karbon yang disimpan oleh tegakan dalam bentuk biomasa dipengaruhi oleh beberapa faktor yakni keragaman jenis pohon, jenis tanah, produksi seresah, dan umur pohon. Faktor tersebut secara tidak langsung akan mengakibatkan perbedaan jumlah karbon yang tersimpan antar lahan. Jumlah karbon antar lahan bergantung pada keragaman dan kerapatan tumbuhan, kesuburan tanah serta cara pengelolaannya. Jumlah biomasa hutan dan cadangan karbon sangat bergantung pada proses fotosintesis, dimana laju fotosintesis tegakan berhubungan dengan kandungan klorofil, jumlah stomata persatuan luas daun, dan umur tegakan. Semakin besar luas daun tegakan persatuan lahan akan semakin meningkatkan besarnya 
$\mathrm{CO}_{2}$ yang diserap oleh tegakan, (Hairiah \& Rahayu, 2007).

Berbagai penelitian diatas melihat hutan memiliki potensial memitigasi perubahan iklim. Penelitian ini penting dilakukan karena hutan selain sebagai pabrik penghasil kayu tapi juga sebagai penyerap karbon yang dapat memitigasi perubahan iklim serta memberikan keuntungan bagi sejumlah pihak.

\section{METODE PENELITIAN}

\section{Waktu dan Lokasi Penelitian}

Penelitian dilaksanakan pada areal dusung dalam hutan rakyat Dusun Toisapu Negeri Hutumuri Kecamatan Leitimur Selatan, Kota Ambon yang secara astronomis terletak pada $03^{\circ} \quad 40^{\prime}$ 06.7" Lintang Selatan dan $128^{\circ} 17^{\prime} 36.8^{\prime \prime}$ Bujur Timur dengan ketinggian lokasi 50-100 dpl. Penelitian Laboratorium dilaksanakan pada Laboratorium Teknologi Fakultas Pertanian Universitas Pattimura Ambon. Penelitian dilaksanakan bulan Agustus 2018 sampai Oktober 2018.

\section{Alat dan Bahan}

$$
\text { Peralatan yang digunakan }
$$

yakni, Phiband, Roll meter, kamera, tali rafia, parang, haga meter, GPS Garmin, Chainsaw, Gergaji tangan, Terpal, Plastik dan Karung, Timbangan 50-100 Kg, Timbangan (digital dan manual), Oven Pengering, Thermometer dan Komputer serta Alat tulis menulis.

Bahan yang digunakan dalam penelitian adalah tegakan skala plot dengan gradient petak ukur $20 \times 20 \mathrm{~m}^{2} ; 10 \times 10 \mathrm{~m}^{2}$ untuk pengukuran tinggi dan diameter tegakan pohon yang bervariasi serta nekromas; gradient petak ukur $5 \times 5 \mathrm{~m}^{2}$ dan $2 \times 2 \mathrm{~m}^{2}$, untuk pengukuran tumbuhan bawah, serasah serta sampel tanah topsoil.

\section{Metode Penelitian}

Pengumpulan data primer dilakukan melalui pengamatan dan pengukuran secara langsung terhadap objek penelitian dilapangan dan laboratorium. Kegiatan penelitian diawali dengan menginventarisasi potensi vegetasi pada tingat semai, pancang, tiang dan pohon. Teknik pengambilan sampel vegetasi dapat dilihat pada tabel 1 . 
Tabel 1. Teknik Pengambilan Sampel dan Pengukuran

\begin{tabular}{|c|c|c|c|c|}
\hline No & $\begin{array}{c}\text { Pengambilan dan } \\
\text { Pengukuran } \\
\text { Biomasa }\end{array}$ & $\begin{array}{c}\text { Teknik Pengambilan } \\
\text { Ring Sampel }\end{array}$ & Keterangan & Pustaka Acuan \\
\hline $\mathbf{A}$ & \multicolumn{4}{|c|}{ Bahan Organik Hidup } \\
\hline & $\begin{array}{l}\text { Vegetasi Tingkat } \\
\text { Tiang dan Pohon, } \\
\text { mengacu pada SNI } \\
7724: 2011\end{array}$ & $\begin{array}{l}\text { Survei vegetasi tingkat } \\
\text { sapihan, } \\
\text { tiang dan pohon } \\
\text { intensitas } 100 \% \\
\text { (perhitungan biomasa } \\
\text { menggunakan persamaan } \\
\text { alometrik dengan peubah }\end{array}$ & $\begin{array}{l}\text { Diambil pada } \\
\text { semua jalur } \\
\text { pengamatan } \\
\text { ukuran lebar dan } \\
\text { panjang jalur } 20 \\
\text { x } 20 \mathrm{~m}^{2} \text {. } \\
\end{array}$ & $\begin{array}{l}\text { Badan Standarisasi Nasional } \\
\text { (BSN) : Standar Nasional } \\
\text { Indonesia (SNI) 7724:2011, } \\
\text { Pengukuran dan penghitungan } \\
\text { cadangan karbon - Pengukuran } \\
\text { lapangan untuk penaksiran } \\
\text { cadangan karbon hutan (ground }\end{array}$ \\
\hline & $\begin{array}{l}\text { Vegetasi Tingkat } \\
\text { Semai dan Pancang, } \\
\text { mengacu pada SNI } \\
7724: 2011\end{array}$ & $\begin{array}{l}\text { Pengambilan ring sampel } \\
\text { rumput berukuran } 300 \\
\text { gram (dilakukan } \\
\text { perhitungan rasio antara } \\
\text { bobot kering terhadap } \\
\text { bobot basah sesuai } \\
\text { hasil kering tanur/oven) }\end{array}$ & $\begin{array}{l}\text { Diambil ring } \\
\text { sampel pada plot } \\
\text { ukur } 2 \text { × } 2 \mathrm{~m}^{2} ; 5 \\
\text { x } 5 \mathrm{~m}^{2} \text { untuk } \\
\text { tumbuhan } \\
\text { bawah, dan } \\
\text { pancang di } \\
\text { dom }\end{array}$ & 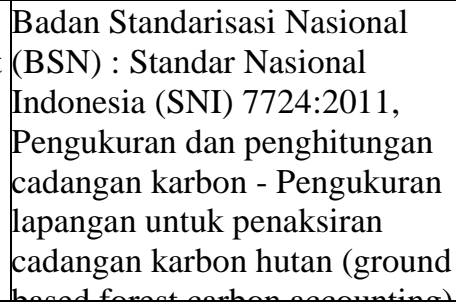 \\
\hline B & \multicolumn{4}{|c|}{ Bahan Organik Mati } \\
\hline & $\begin{array}{l}\text { Seresah, mengacu } \\
\text { pada SNI } \\
7724: 2011\end{array}$ & $\begin{array}{l}\text { Pengambilan ring sampel } \\
\text { seresah berukuran } 300 \\
\text { gram (dilakukan } \\
\text { perhitungan rasio antara } \\
\text { bobot kering terhadap } \\
\text { bobot basah sesuai } \\
\text { hasil kering tanur/oven) }\end{array}$ & $\begin{array}{l}\text { Diambil ring } \\
\text { sampel untuk } \\
\text { serasah ukuran } 2 \\
\text { x } 2 \mathrm{~m}^{2} \text {. }\end{array}$ & $\begin{array}{l}\text { Badan Standarisasi Nasional } \\
\text { (BSN) : Standar Nasional } \\
\text { Indonesia (SNI) 7724:2011, } \\
\text { Pengukuran dan penghitungan } \\
\text { cadangan karbon - Pengukuran } \\
\text { lapangan untuk penaksiran } \\
\text { cadangan karbon hutan (ground }\end{array}$ \\
\hline & $\begin{array}{l}\text { Kayu Mati, } \\
\text { mengacu pada SNI } \\
7724: 2011\end{array}$ & $\begin{array}{l}\text { Pendugaan volume } \\
\text { yang rebah dan } \\
\text { ditemukan dilokasi } \\
\text { penelitian. }\end{array}$ & $\begin{array}{l}\text { Diambil jika } \\
\text { ditemukan kayu } \\
\text { mati }\end{array}$ & $\begin{array}{l}\text { Badan Standarisasi Nasional } \\
\text { (BSN) : Standar Nasional } \\
\text { Indonesia (SNI) 7724:2011, } \\
\text { Pengukuran dan penghitungan } \\
\text { cadangan karbon - Pengukuran } \\
\text { lapangan untuk penaksiran } \\
\text { cadangan karbon hutan (ground }\end{array}$ \\
\hline
\end{tabular}

Teknik pengambilan sampel vegetasi dilakukan dengan Survei vegetasi tingkat sapihan, tiang dan pohon intensitas $100 \%$ (perhitungan menggunakan persamaan alometrik dengan peubah diameter setinggi dada). Diambil pada semua jalur pengamatan ukuran lebar dan panjang petak ukuran $20 \mathrm{x}$ $20 \mathrm{~m}^{2}$ dan $10 \times 10 \mathrm{~m}^{2}$ untuk pengukuran tinggi dan diameter tegakan pohon; petak ukur 5 x 5 $\mathrm{m}^{2}$ dan $2 \times 2 \mathrm{~m}^{2}$, untuk pengukuran tumbuhan bawah.

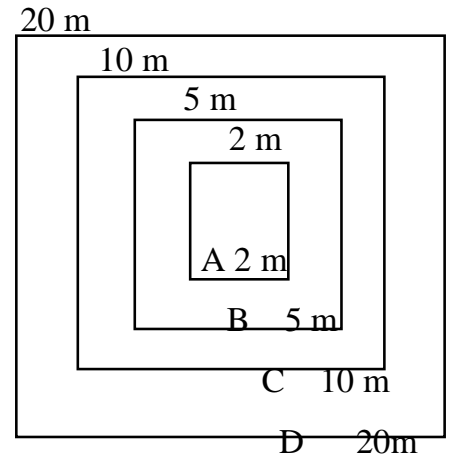

Gambar 2. Bentuk dan Ukuran Plot Pengambilan Sampel

Keterangan gambar :

A : sub plot untuk semai, serasah dan tumbuhan bawah B : sub plot untuk pancang 
C : sub plot untuk tiang

D : sub plot untuk pohon

Analisis Data

Analisis data menggunakan metode perhitungan Nilai INP dihitung berdasarkan penjumlahan nilai Kerapatan Relatif (KR), Frekuensi Relatif (FR) dan Dominansi Relatif (DR). Besarnya INP pada suatu vegetasi dapat dihitung dengan persamaan berikut (Soerianegara dan Indrawan 1983).

Kerapatan $(K)=\frac{\text { Jumlah individu suatu jenis }}{\text { luas seluruh petak contoh }}$

Kerapatan Relatif $(\mathrm{KR})=\frac{\text { Kerapatan suatu jenis }}{\text { Kerapatan seluruh jenis }} x 100 \%$

Frekuensi $(\mathrm{F})=\frac{\text { Jumlah petak ditemukannya suatu jenis }}{\text { Jumlah seluruh petak }}$

Frekuensi Relatif $(\mathrm{FR})=\frac{\text { Frekuensi suatu jenis }}{\text { Frekuensi seluruh jenis }} x 100 \%$

Dominansi (D) $=\frac{\text { Luas basal area suatu spesies }}{\text { Luas seluruh petak contoh }}$

Dominansi Relatif $(\mathrm{DR})=\frac{\text { Dominansi suatu jenis }}{\text { Dominansi seluruh jenis }} \times 100 \%$

Berdasarkan persamaan tersebut, maka untuk menghitung besar INP spesies fase pancang, tiang dan pohon menggunakan rumus berikut :

$$
\mathrm{INP}=\mathrm{KR}+\mathrm{FR}+\mathrm{DR}
$$

Persamaan rata-rata (mean) untuk menghitung data hasil pengambilan ring sampel serasah, biomasa pohon, tiang, pancang, semai dan tumbuhan penutup tanah dan serasah yaitu $: X=\sum X i / n$.

Persamaan alometrik untuk menduga biomasa pohon kawasan agroforestry yang dikembangkan oleh Ketterings et al. (2001) dengan rumus : $\mathrm{Y}=\mathrm{a} \rho \mathrm{Db}$, dimana; $\mathrm{a}=$ intersepsi dengan sumbu $\mathrm{Y} ; \mathrm{b}=\mathrm{BJ}$ kayu $(\mathrm{g} / \mathrm{cm} 3) ; \quad \mathrm{D}=\mathrm{DBH} \quad(\mathrm{cm}) \quad$ dan yang dikembangkan oleh Chave et al, (2005) yakni : (AGB)est $=0.112(\pi * \mathrm{D} 2 \mathrm{H}) 0.916$.

Biomasa per hektar dihitung dengan persamaan sebagai berikut:

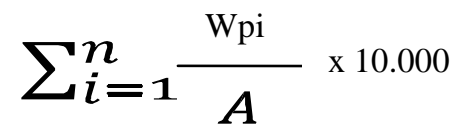

Dimana : W : Total biomasa (ton/ha)

Wpi : Biomassa pohon (ton)

A : Luas plot (m2)

$\mathrm{n}$ : Jumlah pohon

Penentuan nilai potensi karbon di kawasan agroforestry berdasakan hasil inventarisasi tegakan akan diolah dan dihitung untuk memperkirakan jumlah biomasa diatas tanah (above ground biomas), yang dihitung perkiraan jumlah karbon pada sistem agroforestry dengan rumus (Brown, 1997) : C $=0.5 \times$ Y dimana $: \mathrm{C}=$ jumlah karbon dan $\mathrm{Y}$ $=$ jumlah biomasa dan, Penentuan jumlah kandungan karbon tersimpan untuk seluruh plot menggunakan rumus ;

$\mathrm{C}_{\text {plot }}=\left(\mathrm{C}_{\text {bap }}+\mathrm{C}_{\text {serasah }}+\mathrm{C}_{\mathrm{km}}+\mathrm{C}_{\mathrm{pm}}+\mathrm{C}_{\text {tanah }}\right)$

Dimana :

$$
\begin{aligned}
\mathrm{C}_{\text {plot }}= & \text { Total kandungan karbon } \\
& \text { pada plot (ton/ha) } \\
\mathrm{C}_{\text {bap }}= & \text { Total kandungan biomassa } \\
& \text { atas permukaan per hektar } \\
& \text { pada plot (ton/ha) } \\
& \text { Total kandungan karbon } \\
\mathrm{C}_{\text {serasah }}= & \text { biomassa serasah per hektar } \\
& \text { pada plot } \\
\mathrm{C}_{\mathrm{km}}= & \text { Total kandungan karbon } \\
& \text { kayu mati per hektar pada } \\
& \text { plot (ton/ha) } \\
= & \text { Total kandungan karbon } \\
& \text { pohon mati per hektar pada } \\
\mathrm{C}_{\mathrm{pm}} & \text { plot (ton/ha) } \\
= & \text { Total kandungan karbon } \\
& \text { tanah per hektar pada } \\
& \text { plot (ton/ha) }
\end{aligned}
$$

\section{HASIL DAN PEMBAHASAN}




\section{Analisis Vegetasi Pada Plot Pengukuran} Karbon

Keanekaragaman jenis tumbuhan yang terdapat pada setiap hutan rakyat dengan sistem dusung di Pulau Ambon memiliki struktur dan stratifikasi vegetasi yang berbeda. Jumlah dan jenis spesies paling tinggi ditemukan pada hutan tanaman campuran (agroforest) karena lahan hutan telah dikelola oleh masyarakat setempat secara turun temurun dengan diversifikasi tanaman budidaya perennial (buah-buahan, cengkih dan pala). Untuk menentukan kerapatan jenis tanaman vegetasi, maka dipelajari susunan (komposisi jenis) dan bentuk (struktur) vegetasi pada satu hamparan kawasan hutan.

Analisis vegetasi akan menjawab jenis tumbuhan yang dominan dan memberi ciri utama komunitas tanaman ditingkat plot. Ukuran dominansi vegetasi dinyatakan dalam bentuk penutupan tajuk, luas basal area, indeks nilai penting dan perbandingan nilai penting (Indriyanto, 2006).

Hasil penelitian pada ketiga plot pengukuran memiliki variasi jenis vegetasi yang berbeda khusus pada stratifikasi vegetasi tingkat tiang dan pohon berdasarkan hasil inventarisasi jenis tegakan dan perhitungan indeks kerapatan tanaman (Nilai INP) untuk tingkat pohon dan tiang pada plot Plot 1, Plot. 2 dan Plot. 3 pengukuran dengan ukuran luas Plot contoh 0,12 ha menunjukan sebaran jenis tanaman vegetasi seperti pada Tabel berikut;

Tabel 2. Nilai Kerapatan Tegakan Tingkat Pohon pada Tiga Plot Pengukuran

\begin{tabular}{|c|l|r|r|r|r|r|c|r|r|}
\hline No & \multicolumn{1}{|c|}{ Jenis Pohon } & \multicolumn{1}{|c|}{ K } & \multicolumn{1}{c|}{ KR } & \multicolumn{1}{c|}{ F } & \multicolumn{1}{c|}{ FR } & \multicolumn{1}{c|}{ D } & \multicolumn{1}{c|}{ DR } & INP \\
\hline 1 & Pala (Myristica fragrans) & 9 & 7,5 & 12,33 & 0,67 & 18,18 & 0,22 & 9,39 & 39,9 \\
\hline 2 & Durian (Durio zibethinus) & 27 & 22,5 & 36,99 & 0,67 & 18,18 & 0,73 & 31,47 & 86,6 \\
\hline 3 & Langsat (Lansium sp) & 6 & 5 & 8,22 & 1 & 27,27 & 0,17 & 7,53 & 43 \\
\hline 4 & Duku (Lansium domestisum) & 25 & 20,83 & 34,25 & 1 & 27,27 & 0,96 & 41,52 & 103 \\
\hline 5 & 6 & 5 & 8,22 & 0,33 & 9,09 & 0,23 & 10,09 & 27,4 \\
\hline & $\begin{array}{l}\text { aromatica) } \\
\text { areugenia }\end{array}$ & $\mathbf{7 3}$ & $\mathbf{6 0 , 8 3}$ & $\mathbf{1 0 0}$ & $\mathbf{3 , 6 7}$ & $\mathbf{1 0 0}$ & $\mathbf{2 , 3 2}$ & $\mathbf{1 0 0}$ & $\mathbf{2 9 9}$ \\
\hline
\end{tabular}

Sumber: Data Penelitian (Diolah, 2018)

Sebaran jenis tanaman yang dominan pada ketiga plot untuk tingkat pertumbuhan pohon didominasi oleh 5 jenis tanaman, yaitu Pala (Myristica fragrans), dengan nilai INP = 39,9, Durian (Durio zibethinus) dengan nilai INP $=86,6$, Langsat (Lansium $s p$ ) dengan nilai INP $=43$, Duku (Lansium domestisum) dengan nilai $\mathrm{INP}=103$ dan Cengkeh (Eugenia aromatica) dengan nilai INP $=27,4$.
Berdasarkan hasil perhitungan kerapatan vegetasi, maka tanaman yang memiliki nilai INP terbesar adalah tanaman duku diikuti tanaman durian dan terakhir adalah tanaman cengkeh.

Berdasarkan hasil analisa vegetasi pada Tabel 5.1, disimpulkan bahwa untuk tegakan tingkat pohon maka tanaman duku dan langsat menyebar lebih merata dibanding jenis yang 
lain. Ini ditandai dengan kategori nilai frekuensi kedua jenis tanaman ini adalah yang lebih besar dari jenis tanaman lainnya. Sedangkan pohon durian dan duku memiliki lebih banyak jumlah jenis per satuan luas dibanding jenis tanaman lainnya sehingga nilai kerapatan tanamannya juga adalah lebih besar. Selain itu tanaman duku dan durian pun memiliki nilai dominansi yang lebih besar sehingga ke-2 jenis ini lebih menguasai ruang tumbuh dalam komunitas vegetasi di untuk masing-masing plot pengukuran.

Sebaran jenis tanaman untuk ketiga plot tiang ada 6 jenis, yakni jenis tanaman Pala, Durian, Langsat, Duku, Manggis dan Cengkeh. Berdasarkan hasil perhitungan nilai INP, maka tanaman yang memiliki nilai INP terbesar adalah jenis tanaman Langsat dengan nilai $\mathrm{INP}=92,5$, diikuti masing-masing jenis tanaman Pala dengan nilai $\mathrm{INP}=60,9$, Durian dengan nilai INP $=51,4$, Duku dengan nilai INP $=41,6$, Cengkeh dengan nilai INP = 32,5; dan yang terkecil adalah Manggis dengan nilai INP $=21,1$. Sebaran jenis tanaman pada ketiga plot pengukuran karbon lokasi penelitian dapat dilihat pada Tabel

\begin{tabular}{|c|l|r|r|r|r|r|r|r|r|}
\hline No & \multicolumn{1}{|c|}{ Jenis Tiang } & \multicolumn{1}{c|}{ K } & \multicolumn{1}{c|}{ KR } & \multicolumn{1}{c|}{ F } & \multicolumn{1}{c|}{ FR } & \multicolumn{1}{c|}{ D } & \multicolumn{1}{c|}{ DR } & INP \\
\hline 1 & Pala (Myristica fragrans) & 22 & 73,33 & 36,07 & 0,67 & 13,33 & 0,28 & 11,51 & 60,9 \\
\hline 2 & Durian (Durio zibethinus) & 8 & 26,67 & 13,11 & 1 & 20 & 0,45 & 18,29 & 51,4 \\
\hline 3 & Langsat(Lansium sp) & 19 & 63,33 & 31,15 & 1 & 20 & 1,01 & 41,37 & 92,5 \\
\hline 4 & Duku (Lansium domesticum) & 5 & 16,67 & 8,2 & 1 & 20 & 0,33 & 13,4 & 41,6 \\
\hline 5 & Manggis (Garcinia manggostana) & 2 & 6,67 & 3,28 & 0,67 & 13,33 & 0,11 & 4,46 & 21,1 \\
\hline 6 & Cengkeh (Eugenia aromatica) & 5 & 16,67 & 8,2 & 0,67 & 13,33 & 0,27 & 10,98 & 32,5 \\
\hline & JUMLAH & $\mathbf{6 1}$ & $\mathbf{2 0 3 , 3 3}$ & $\mathbf{1 0 0}$ & $\mathbf{5}$ & $\mathbf{1 0 0}$ & $\mathbf{2 , 4 5}$ & $\mathbf{1 0 0}$ & $\mathbf{3 2 1}$ \\
\hline
\end{tabular}

contoh pada tingkatan pertumbuhan tingkat berikut.

Tabel 3. Nilai Kerapatan Tegakan Tingkat Tiang pada 3 Plot Pengukuran Karbon

Sumber : Data Penelitian (Diolah, 2018)

Berdasarkan hasil analisis vegetasi tingkat tiang sesuai informasi tabel diatas, bahwa jenis tanaman duku, durian dan langsat menyebar sangat merata dibanding jenis tanaman lainnya.

Hal ini ditandai dengan besarnya nilai frekuensi yang terlihat berdasarkan hasil pengukuran dan perhitungan. Namun bila dilihat dari nilai rataaan terhadap keseluruhan sebaran jenis tanaman vegetasi tingkat tiang bersifat seragam karena hasil penilaian terhadap nilai frekuensi untuk semua jenis tanaman tidak menunjukan perbedaan yang signifikan.

Untuk jenis tanaman pala dan langsat memiliki lebih banyak jumlah tanaman per satuan luas bidang dasar dibanding dengan ketiga jenis tanaman lainnya, karena nilai kerapatan tanaman tersebut adalah lebih besar.

Selain itu tegakan tanaman langsat dan durian pun memiliki nilai dominansi yang lebih besar karena sifat dan karakter pohon yang menguasai hamper sebagian besar komunitas vegetarsi di lokasi penelitian. 
Menurut Martono (2012), indeks keanekaragaman spesies merupakan informasi penting tentang suatu komunitas. Semakin luas areal sampel dan semakin banyak spesies yang dijumpai, maka nilai indeks keanekaragaman spesies cenderung akan lebih tinggi.
Nilai indeks keanekaragaman yang relatif rendah umum dijumpai pada komunitas yang telah mencapai klimaks.

Data pada tabel di atas sangat relevan dengan pendapat bahwa baik untuk jenis pertumbuhan tingkat pohon maupun tingkat tiang diperoleh nilai indeks keanekaragaman yang relatif sama, seperti pada Tabel berikut.

Tabel 4. Indeks Keragaman Vegetasi Pada 3 Plot Pengukuran

\begin{tabular}{|c|l|c|l|c|}
\hline No & \multicolumn{1}{|c|}{ Jenis Pohon } & $\begin{array}{c}\text { Indeks } \\
\text { Shannon- } \\
\text { Winner (H) }\end{array}$ & \multicolumn{1}{|c|}{ Jenis Tiang } & $\begin{array}{c}\text { Indeks } \\
\text { Shannon- } \\
\text { Winner (H) }\end{array}$ \\
\hline 1 & $\begin{array}{l}\text { Pala (Myristica } \\
\text { fragrans) }\end{array}$ & 0,26 & Pala (Myristica fragrans) & 0,37 \\
\hline 2 & $\begin{array}{l}\text { Durian (Durio } \\
\text { zibethinus) }\end{array}$ & 0,37 & Durian (Durio zibethinus) & 0,27 \\
\hline 3 & Langsat (Lansium sp) & 0,21 & Langsat (Lansium sp) & 0,36 \\
\hline 4 & $\begin{array}{l}\text { Duku (Lansium } \\
\text { domesticum) }\end{array}$ & 0,37 & $\begin{array}{l}\text { Duku (Lansium } \\
\text { domesticum) }\end{array}$ & 0,21 \\
\hline 5 & $\begin{array}{l}\text { Cengkeh (Eugenia } \\
\text { aromatica) }\end{array}$ & 0,21 & $\begin{array}{l}\text { Manggis (Garcinia } \\
\text { manggostana) }\end{array}$ & 0,11 \\
\hline 6 & & $\begin{array}{l}\text { Cengkeh (Eugenia } \\
\text { aromatica) }\end{array}$ & 0,21 \\
\hline
\end{tabular}

Sumber: Data Penelitian (Diolah 2018)

Pada ketiga plot pengukuran karbon dimana tegakan tingkat pohon dengan nilai indeks keanekaragaman berkisar antara 0,21 - 0,37, sedangkan pada tegakan tingkat tiang, nilai indeks keanekaragaman berkisar antara $0,11-0,37$

Berdasarkan kriteria indeks keanekaragaman Shannon-Winer, maka untuk ke-2 tingkatan pertumbuhan tegakan ini memiliki keanekaragaman yang rendah.

Hal ini dapat dimengerti karena kawasan tersebut merupakan kawasan hutan tanaman rakyat atau agrofotrestry sistem dusung yang telah menjadi kawasan hutan tanaman rakyat yang dijaga kelestariannya dan kebutuhan masyarakat sekitar kawasan hutan rakyat tersebut.

\section{Pendugaan Biomasa Pohon Tersimpan}

Penentuan plot ukur berdasarkan sebaran jenis tanaman pada hutan rakyat di Dusun Toisapu Negeri. Hutumuri menjadi pertimbangan terhadap pengukuran biomassa berdasarkan tinggi dan diameter jenis tanaman.

Adapun nilai hasil pengukuran biomasa tanaman berdasarkan tinggi dan diameter pohon untuk tiap plot disajikan pada Tabel berikut: 
Tabel 5. Hasil Pengukuran Biomasa Pohon Tersimpan Pada Plot 1

\begin{tabular}{|c|c|c|c|c|c|}
\hline Jenis Vegetasi & $\begin{array}{l}\emptyset \\
(C \\
m)\end{array}$ & $\begin{array}{c}\text { TBC } \\
(\mathbf{M})\end{array}$ & TT (M) & $\begin{array}{c}\text { Volume } \\
\left(\mathbf{m}^{2}\right)\end{array}$ & Biomassa (g) \\
\hline \multicolumn{6}{|l|}{ Pohon } \\
\hline $\begin{array}{l}\text { Durian (Durio } \\
\text { zibethinus) }\end{array}$ & 68 & 16,5 & 28 & 4,165762 & 4453,957 \\
\hline Pala (Myristica fragrans) & 22 & 2,5 & 22 & 0,066066 & 180,930 \\
\hline Pala (Myristica fragrans) & 21 & 2,9 & 18,5 & 0,069828 & 160,169 \\
\hline $\begin{array}{l}\text { Durian (Durio } \\
\text { zibethinus) }\end{array}$ & 42 & 18 & 25 & 1,733659 & 1260,334 \\
\hline Pala (Myristica fragrans) & 21 & 4,3 & 23 & 0,103538 & 160,169 \\
\hline Langsat (Lansium sp) & 20 & 4,8 & 17 & 0,104832 & 146,587 \\
\hline Pala (Myristica fragrans) & 31 & 4,2 & 25 & 0,220377 & 444,355 \\
\hline $\begin{array}{l}\text { Durian (Durio } \\
\text { zibethinus) }\end{array}$ & 93 & 15 & 24 & 7,083531 & 10115,748 \\
\hline \multicolumn{6}{|l|}{ Tiang } \\
\hline Pala (Myristica fragrans) & 9,2 & 17 & 19 & 0,078563 & 18,428 \\
\hline Total Biomassa & & & & & 16940,676 \\
\hline
\end{tabular}

Tabel 6. Hasil Pengukuran Biomasa Pohon Tersimpan Pada Plot 2

\begin{tabular}{|c|c|c|c|c|c|}
\hline Jenis Vegetasi & $\begin{array}{c}\varnothing \\
(\mathbf{C m}) \\
\end{array}$ & $\begin{array}{l}\text { TBC } \\
(\mathrm{M}) \\
\end{array}$ & $\begin{array}{l}\text { TT } \\
(\mathrm{M})\end{array}$ & $\begin{array}{c}\text { Volume } \\
\left(\mathbf{m}^{2}\right)\end{array}$ & $\begin{array}{c}\text { Biomassa } \\
(\mathrm{g})\end{array}$ \\
\hline \multicolumn{6}{|l|}{ Pohon } \\
\hline Durian (Durio zibethinus) & 57,5 & 15 & 28 & 2,707819 & 2870,136 \\
\hline Durian (Durio zibethinus) & 77,5 & 14,5 & 20,5 & 4,755148 & 6273,980 \\
\hline Durian (Durio zibethinus) & 44 & 8 & 15 & 0,845645 & 1423,701 \\
\hline Durian (Durio zibethinus) & 59 & 8,5 & 11 & 1,615532 & 3070,471 \\
\hline Durian (Durio zibethinus) & 50 & 21,5 & 35 & 2,93475 & 1990,096 \\
\hline Durian (Durio zibethinus) & 58 & 8 & 17 & 1,469395 & 2935,986 \\
\hline Durian (Durio zibethinus) & 41 & 18 & 32 & 1,652087 & 1183,222 \\
\hline Durian (Durio zibethinus) & 65,5 & 14 & 28 & 3,279467 & 4037,615 \\
\hline Durian (Durio zibethinus) & 41 & 18 & 28,2 & 1,652087 & 1183,222 \\
\hline $\begin{array}{l}\text { Duku (Lansium } \\
\text { domesticum) }\end{array}$ & 20,2 & 7 & 12,7 & 0,155953 & 162,032 \\
\hline $\begin{array}{l}\text { Duku (Lansium } \\
\text { domesticum) }\end{array}$ & 23,9 & 4,5 & 14,5 & 0,140346 & 251,758 \\
\hline Pala (Myristica fragrans) & 24,5 & 2 & 15,7 & 0,065547 & 239,871 \\
\hline Durian (Durio zibethinus) & 54,3 & 15 & 22,4 & 2,414813 & 2470,292 \\
\hline \multicolumn{6}{|l|}{ Tiang } \\
\hline Durian (Durio zibethinus) & 11,4 & 7 & 9 & 0,049671 & 41,368 \\
\hline Langsat (Lansium $s p$ ) & 16,7 & 6,5 & 13 & 0,098978 & 91,393 \\
\hline Langsat (Lansium $s p$ ) & 11 & 5,5 & 8 & 0,036336 & 30,609 \\
\hline Langsat (Lansium $s p$ ) & 13,8 & 6 & 10 & 0,062388 & 55,447 \\
\hline Langsat (Lansium $s p$ ) & 13,7 & 10 & 13,6 & 0,102479 & 54,401 \\
\hline Total Biomassa & & & & & 28365,60 \\
\hline
\end{tabular}


Tabel 7. Hasil Perhitungan Biomassa Pohon Tersimpan Pada Plot 3

\begin{tabular}{|c|c|c|c|c|c|}
\hline Jenis Vegetasi & $\varnothing(\mathrm{Cm})$ & TBC (M) & TT (M) & Volume $\left(\mathrm{m}^{2}\right)$ & Biomassa (g) \\
\hline \multicolumn{6}{|l|}{ Pohon } \\
\hline Duku (Lansium domesticum) & 26 & 4,5 & 15 & 0,166093 & 313,914 \\
\hline $\begin{array}{l}\text { Cengkeh (Eugenia } \\
\text { aromatica) }\end{array}$ & 22 & 5,5 & 14 & 0,145345 & 434,232 \\
\hline Duku (Lansium domesticum) & 20 & 1,3 & 16,5 & 0,028392 & 157,863 \\
\hline Duku (Lansium domesticum) & 24 & 3,2 & 11 & 0,100639 & 254,527 \\
\hline Durian (Durio zibethinus) & 27 & 7 & 15 & 0,278624 & 136,895 \\
\hline Durian (Durio zibethinus) & 20 & 9 & 13 & 0,19656 & 70,864 \\
\hline \multicolumn{6}{|l|}{ Tiang } \\
\hline Duku (Lansium domesticum) & 10 & 1,5 & 7 & 0,00819 & 25,679 \\
\hline Duku (Lansium domesticum) & 17 & 3,3 & 7,5 & 0,052072 & 103,123 \\
\hline Pala (Myristica fragrans) & 10 & 5 & 6,5 & 0,0273 & 12,778 \\
\hline Total Biomassa & & & & & $\mathbf{1 5 0 9 , 8 7 5}$ \\
\hline
\end{tabular}

Data tabel pada plot 1, plot 2 dan plot 3 karena vegetasi hutan menyerap karbon menunjukan bahwa biomasa tersimpan yang tertinggi didominasi jenis tanaman Durian dioksida melalui aktivitas fotosintesis dan kemudian tanaman Pala dan tanaman Langsat. mampu menyimpan sekitar $76-78 \%$ karbon Namun jika dibandingkan nilai biomassa antar organik dari total karbon organik daratan dalam bentuk biomasa (Kun and Dongsheng, plot, maka plot 2 memiliki nilai tertinggi 2008). sebab pada plot ini dominan merupakan Besarnya kandungan karbon dan tanaman Durian dibandingkan dengan plot 1 yang adalah dominan tanaman Pala dan plot 3 dominan tanaman Langsat dan Duku.

Tresnawan dan Rosalina (2002) menyebutkan bahwa kajian biomasa hutan merupakan suatu langkah awal penelitian produktivitas serta sangat penting dipelajari untuk mengetahui siklus hara dan aliran energi dari suatu ekosistem hutan tropika.

Proses penimbunan karbon dalam tubuh tanaman hidup dikenal sebagai sekuestrasi $(C$ Sequestration), (Hairiah dan Rahayu, 2007).

\section{Pengukuran Karbon dari Biomassa}

Vegetasi Tiang dan Pohon

Hutan dataran rendah menyimpan sebagian besar kandungan karbon daratan

biomasa pohon bervariasi berdasarkan bagian tumbuhan yang diukur, growth stage, tingkatan tumbuhan dan kondisi lingkungannya. Kandungan karbon dan biomasa tumbuhan bawah dipengaruhi oleh jenis-jenis tumbuhan penyusun (Asril, 2008).

Berdasarkan hasil penelitian yang telah dilakukan di Hutan Rakyat Negeri Hutumuri, pada 3 plot yang diukur berdasarkan penempatan plot sesuai kombinasi jenis tanaman untuk dominan jenis tanaman Pala pada Plot 1, tanaman Durian pada Plot 2 dan tanaman Duku pada Plot 3 dapat digambarkan pada tabel berikut. 
Tabel 8. Kandungan Karbon, Biomasa Tegakan Tiang dan Pohon

\begin{tabular}{|c|c|c|c|c|}
\hline Plot & Tegakan Pohon dan Tiang & $\sum$ Volume & $\sum$ Biomassa & Total C \\
\hline I & Pala, Durian, Langsa & 16,692 & 18613,54 & 9306,77 \\
\hline II & Durian, Duku, Pala, Langsa & 27,384 & 30414,89 & 15207,44 \\
\hline III & Duku, Cengkeh, Durian, Langsa, Pala & 1,654 & 1755,34 & 877,67 \\
\hline & & 45,73056 & 50783,77 & \\
\hline & \multicolumn{2}{|c|}{ Jumlah Biomassa $\mathrm{Kg} / \mathrm{m}^{2}$} & 25391,88 & \\
\hline & & Ton/Ha & 2539,19 & \\
\hline
\end{tabular}

Gambaran hasil pengukuran biomassa tingkat tiang dan pohon untuk memprediksi kandungan karbon pada plot 1, 2 dan 3 disajikan pada grafik berikut;

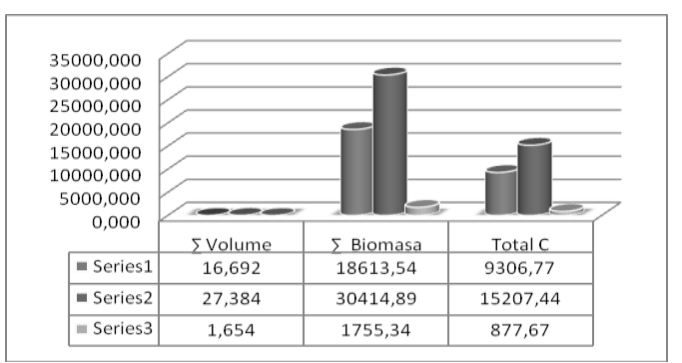

Gambar 3. Hasil Pengukuran Jumlah Biomassa Tegakan Tingkat Tiang dan Pohon.

Berdasarkan perhitungan nilai biomasa terhadap jumlah kandungan karbon pada ketiga plot menunjukan bahwa potensi biomasa untuk total luas petak ukur $400 \mathrm{~m}^{2}$ atau 0,04 ha untuk ketiga plot total luas 1200 $\mathrm{m}^{2}$ atau 0,12 ha memiliki jumlah total biomassa $50.783,77 \mathrm{~kg} / \mathrm{m}^{2}$ yang dikalikan dengan asumsi $0,5 \%$ dari total jumlah biomassa pohon dan tiang sehingga jumlah kandungan karbon yang tersimpan pada ketiga plot sebesar $25.391,88 \mathrm{~kg} / \mathrm{m}^{2}$ atau $2.539,19$ ton/ha.

Hasil pengukuran diameter dan tinggi struktur vegetasi tingkat tiang dan pohon pada tabel dan grafik di atas menunjukan bahwa jumlah volume pohon yang dihitung sangat berbeda terhadap jumlah nilai biomasa yang dihasilkan. Hal ini dapat dilihat dari kandungan biomasa yang tersimpan pada jenis vegetasi berdasarkan ukuran diameter dan tinggi tanaman. Kondisi ini menunjukkan bahwa semakin besar ukuran diameter batang suatu tumbuhan, maka semakin tinggi pula nilai biomasa tumbuhan tersebut. Begitu juga dengan besarnya kandungan karbon dan biomasa pohon bervariasi berdasarkan bagian tumbuhan yang diukur, growth stage, tingkatan tumbuhan dan kondisi lingkungannya, (Suwardi, 2004).

\section{Pengukuran Karbon dari Biomassa Tumbuhan Bawah}

Kerapatan tajuk atau tegakan tanaman merupakan faktor yang mempengaruhi pertumbuhan tanaman hutan karena adannya persaingan untuk mendapatkan sinar matahari. Ciri khas keberadaan formasi tumbuhan bawah dalam suatu ekosisitem hutan sangat dipengaruhi oleh kemampuan hidup dan bertahan.

Pada saat melakukan pemanenan secara destruktif jenis-jenis tumbuhan bawah yang ditemukan umumnya bervariasi jenis mulai dari yang tumbuh merambat seperti rerumputan sampai yang tumbuh sporadis berdasarkan faktor tempat tumbuh (site) ataupun anakan dari tanaman induk yang tumbuh di bawah naungan inang. 
Hasil jumlah biomasa tumbuhan bawah pada ketiga plot yang dilakukan pengambilan sampel secara destruktif setelah dilakukan penimbangan dan perhitungan berat kering, disajikan pada tabel berikut.

Tabel 9. Kandungan Karbon dari Biomassa Tumbuhan Bawah

\begin{tabular}{|c|c|c|c|c|}
\hline \multirow{2}{*}{$\begin{array}{l}\text { Plot } \\
\text { Ukur }\end{array}$} & \multirow{2}{*}{$\begin{array}{c}\text { Tumbuhan } \\
\text { Bawah }\end{array}$} & \multicolumn{2}{|c|}{ Nilai Biomasa } & \multirow{2}{*}{$\begin{array}{r}\text { Nilai C } \\
\text { Organil } \\
\mathrm{Kg} / \mathrm{m}^{2}\end{array}$} \\
\hline & & $\mathrm{g} / \mathrm{m}^{2}$ & $\mathrm{Kg} / \mathrm{m}^{2}$ & \\
\hline $\mathrm{I}$ & 29 & 29 & 0,029 & 0,0145 \\
\hline II & 141 & 141 & 0,141 & 0,0705 \\
\hline III & 91 & 91 & 0,091 & 0,0455 \\
\hline \multicolumn{3}{|c|}{$\operatorname{Jumlah} \operatorname{Karbon}\left(\mathrm{Kg} / \mathrm{m}^{2}\right)=$} & 0,261 & 0,1305 \\
\hline
\end{tabular}

Total jumlah biomasa Tumbuhan Bawah memiliki nilai berbeda dari ketiga plot pengukuran, ditampilkan pada grafik berikut;

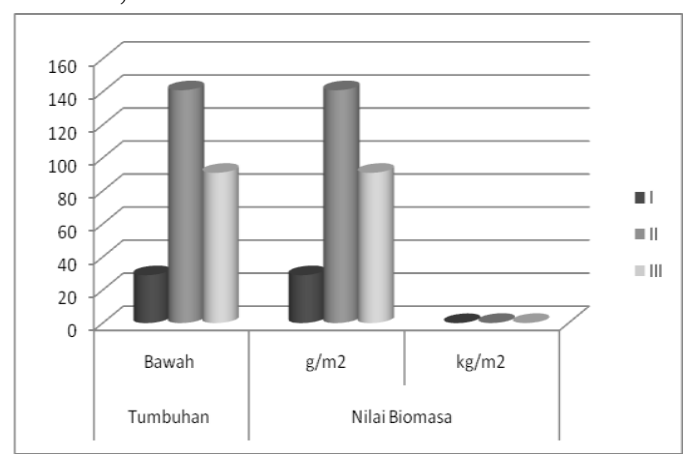

Gambar 4. Hasil Pengukuran Jumlah Biomassa pada 3 Plot Tumbuhan Bawah Hasil perhitungan pada tabel diatas menunjukan bahwa ada perbedaan yang signifikan terkait jumlah biomasa tumbuhan basah yang diukur dari ketiga plot berukuran 2 x 2. Nilai biomasa berbeda ini secara langsung akan menggambarkan keberadaan jumlah dan nilai karbon yang diperoleh tiap plotnya.

Hasil pengukuran menunjukan bahwa plot 1 memiliki nilai biomasa yang rendah sebesar $0,029 \mathrm{Kg} / \mathrm{m}^{2}$, demplot 3 dengan jumlah biomasa $0,091 \mathrm{Kg} / \mathrm{m}^{2}$ dan demplot 2 dengan jumlah biomasa $0,141 \mathrm{Kg} / \mathrm{m}^{2}$ sehingga ketiga plot dengan nilai biomasa sebesar $0,261 \mathrm{Kg} / \mathrm{m}^{2}$.

Berdasarkan perhitungan nilai biomassa terhadap jumlah kandungan karbon tumbuhan bawah

pada ketiga plot menunjukan bahwa potensi biomasa untuk total luas petak ukur 2 x $2 \mathrm{~m}^{2}$ untuk 3 plot seluas $12 \mathrm{~m}^{2}$ atau 0,0012 ha memiliki jumlah total biomasa 0,261 $\mathrm{Kg} / \mathrm{m}^{2}$ yang dikalikan dengan asumsi $0,5 \%$ dari total jumlah tumbuhan bawah sehingga jumlah kandungan karbon yang tersimpan pada ketiga plot sebesar $0,1305 \mathrm{Kg} / \mathrm{m}^{2}$.

Menurut Brown (1997:10), jumlah biomasa yang dihasilkan oleh tumbuhan bawah seperti semak-semak, tumbuhan merambat, dan herbal dapat bervariasi, tetapi umumnya pada kebanyakan hutan persentasenya sekitar $3 \%$ dari total keseluruhan biomasa diatas permukaan.

Kandungan karbon dan biomasa tumbuhan bawah dipengaruhi oleh jenis-jenis tumbuhan penyusun (Asril, 2009). Hariadi (2000) menyatakan bahwa terdapat beberapa jenis tumbuhan rerumputan terestrial yang menyukai cahaya yang dominan, seperti jenis-jenis mirtaceae $s p$ dan gramineae $s p$.

\section{Pengukuran Karbon dari Bahan Organik Mati (Serasah dan Kayu Mati)}

Serasah merupakan salah satu komponen di dalam hutan yang juga dapat menyimpan karbon. Hasil pengukuran yang telah dilakukan dari kedua sumber karbon bahan organik mati (serasah, dan kayu mati) 
pada ketiga plot pengukuran karbon disajikan pada tabel berikut;

Tabel 10. Kandungan Karbon dari Biomassa Serasah

Total jumlah biomasa serasah halus dan kasar hasil pengukuran memiliki nilai berbeda dari ketiga plot yang diukur, ditampilkan pada grafik berikut;

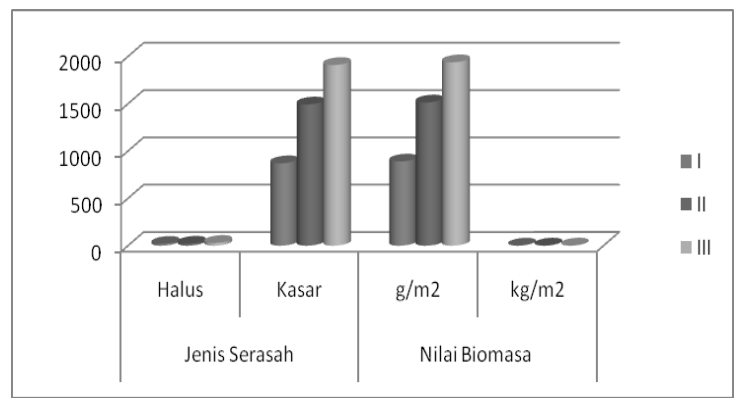

Gambar 5. Hasil Pengukuran Jumlah Biomass dari Serasah Halus dan Kasar

Nilai hasil pengukuran biomasa serasah terkecil pada plot 1sebesar 0,89 $\mathrm{Kg} / \mathrm{m}^{2}$, kemudian pada plot 2 sebesar 1,514 $\mathrm{Kg} / \mathrm{m}^{2}$ dan pada plot 3 sebesar $1,939 \mathrm{Kg} / \mathrm{m}^{2}$. Hasil jumlah pengukuran untuk luasan petak ukur $2 \times 2 \mathrm{~m}^{2}$ atau seluas $12 \mathrm{~m}^{2}$ atau 0,0012 ha memiliki jumlah total biomasa ketiga plot sebesar $4,343 \mathrm{Kg} / \mathrm{m}^{2}$ yang dikalikan dengan asumsi 0,5 \% dari total jumlah serasah, sehingga jumlah kandungan karbon yang tersimpan pada ketiga plot sebesar 2,1715 $\mathrm{Kg} / \mathrm{m}^{2}$.

Serasah didefinisikan sebagai bahan organik mati yang berada diatas tanah/lantai hutan (Sutaryo, 2009). Keberadaan biomasa selain ditemukan tersimpan pada pohon dan tumbuhan bawah, biomasa di atas permukaan (above ground), maka biomasa juga terdapat dalam bentuk serasah. Serasah berfungsi sebagai penyimpan air sementara, memperbaiki struktur tanah, dan menaikkan kapasitas penyerapan. Melalui fotosintesis, CO2 diserap dan diubah oleh tumbuhan menjadi karbon organik dalam bentuk biomassa. Nilai hasil pengukuran jumlah biomasa kayu mati (nekromas) sesuai dengan sebaran tegakan yang menempati plot pengukuran karbon di hutan rakyat Dusun Toisapu dapat sajikan pada grafik berikut;

\begin{tabular}{|c|c|c|c|c|c|}
\hline \multirow{2}{*}{$\begin{array}{c}\text { Plot } \\
\text { Ukur }\end{array}$} & \multicolumn{2}{|c|}{ Jenis Serasah } & \multicolumn{2}{c|}{ Nilai Biomassa } & $\begin{array}{c}\text { Nilai C } \\
\text { Organik }\end{array}$ \\
\cline { 2 - 6 } & Halus & Kasar & $\mathbf{g} / \mathbf{m}^{\mathbf{2}}$ & $\mathbf{K g} / \mathbf{m}^{\mathbf{2}}$ & $\mathbf{K g} / \mathbf{m}^{\mathbf{2}}$ \\
\hline I & 19 & 871 & 890 & 0,89 & 0,4450 \\
\hline II & 21 & 1493 & 1514 & 1,514 & 0,7570 \\
\hline III & 29 & 1910 & 1939 & 1,939 & 0,9695 \\
\hline \multicolumn{4}{|c|}{ Jumlah Karbon $\left(\mathbf{K g} / \mathbf{m}^{\mathbf{2}}\right)$} & $\mathbf{4 , 3 4 3}$ & $\mathbf{2 , 1 7 1 5}$ \\
\hline
\end{tabular}

Gambar 6. Hasil Pengukuran Jumlah Biomass dari Kayu Mati (Nekromas)

Hasil pengukuran serasah kayu mati (nekromas) pada ketiga plot pengukuran dengan nilai berbeda untuk plot 1 dengan nilai terendah $0,291 \mathrm{Kg} / \mathrm{m}^{2}$, diikuti plot 2 sebesar $0,939 \mathrm{Kg} / \mathrm{m}^{2}$ dan plot 3 sebesar $3,179 \mathrm{Kg} / \mathrm{m}^{2}$. Hasil pengukuran jumlah biomasa untuk luasan petak ukur $20 \times 20 \mathrm{~m}^{2}$ ketiga demplot seluas $1200 \mathrm{~m}^{2}$ atau 0,12 ha memiliki jumlah total biomasa sebesar $4,410 \mathrm{Kg} / \mathrm{m}^{2}$ yang dikalikan dengan asumsi $0,5 \%$ dari total jumlah biomasa kayu mati (nekromas), sehingga jumlah kandungan karbon yang tersimpan pada ketiga demplot sebesar 2,203 $\mathrm{Kg} / \mathrm{m}^{2}$ atau 22,048 ton/ha.

Lapisan serasah atau lantai hutan merupakan seluruh bahan organik mati yang berada diatas permukaan tanah. Beberapa material 
organik dapat dikenali atau masih sedikit terdekomposisi (Pearson dkk.2005).

Mikroorganisme tanah sangat berperan terhadap dekomposisi bahan organik tanah dan pelepasan $\mathrm{CO} 2$. Mengukur jumlah karbon dalam biomasa pada suatu lahan menggambarkan banyaknya $\mathrm{CO} 2$ di atmosfer yang diserap oleh tanaman, dan pengukuran karbon dalam bagian tanaman yang telah mati (nekromas) dapat menggambarkan $\mathrm{CO} 2$ yang tidak dilepaskan ke udara melalui pembakaran (Barchia, 2009).

\section{KESIMPULAN DAN SARAN}

\section{Kesimpulan}

Jumlah Biomasa Pohon dan Tiang sesuai pengukuran berbeda-beda, dimana tertinggi pada plot 2 sebesar $30414,89 \mathrm{Kg} / \mathrm{m}^{2}$; diikuti plot 1 sebesar $18613,54 \mathrm{Kg} / \mathrm{m}^{2}$ dan terendah plot 3 sebesar $1755,34 \mathrm{Kg} / \mathrm{m}^{2}$ dengan total jumlah biomasa ketiga plot sebesar 50783,77 Kg/m². demikian halnya Jumlah Biomassa Tumbuhan Bawah sebesar 0,261 Kg/m²; Jumlah Biomasa Serasah Kasar dan Halus sebesar $4.343 \mathrm{Kg} / \mathrm{m}^{2}$; Jumlah Biomasa Kayu Mati (Nekromas) sebesar $4.410 \mathrm{Kg} / \mathrm{m}^{2}$; Jumlah $\mathrm{C}$ organic tanah sebesar $4.423 \mathrm{Kg} / \mathrm{m}^{2}$. sehingga hasil perhitungan serapan karbon tersimpan ketiga plot dari setiap parameter; Pohon dan Tiang 25.391,88 $\mathrm{Kg} / \mathrm{m}^{2}$ atau 99,97 \%; Tumbuhan Bawah $0,1305 \mathrm{Kg} / \mathrm{m}^{2}$ atau $0,001 \%$; Serasah 4,410 $\mathrm{Kg} / \mathrm{m}^{2}$ atau $0,02 \%$; Kayu Mati (Nekromas) $2,1715 \mathrm{Kg} / \mathrm{m}^{2}$ atau $0,01 \%$. Sedangkan biomassa pohon dan tiang, tumbuhan bawah, serasah (kasar dan halus) dan kayu mati, serapan karbon tersimpan diatas permukaan adalah $25.398,60 \mathrm{Kg} / \mathrm{m}^{2}$ atau $2.539,86$ ton/ha. Sedangkan sistem penggunaan lahan dalam memberikan kontribusi cadangan karbon diasumsikan $46 \%$, maka nilai cadangan karbon pada agroforestry sistem dusung diperoleh cadangan karbon tersedia sebesar $11.683,36 \mathrm{Kg} / \mathrm{m}^{2}$.

\section{Saran}

Olehnya disarankan agar dilakukan kajian penelitian yang lebih luas terhadap sistem penggunaan lahan agroforestry dusung untuk mendapatkan data potensi jenis tanaman hutan rakyat di wilayah Maluku dan dilakukan pembinaan masyarakat petani dusung dalam melakukan pengukuran karbon secara sederhana dalam menentukan jumlah karbon tersimpan pada tanaman yang diusahakan.

Selaian itu, perlu dilakukan pelatihan bagi petani, bagaimana menentukan pemetaan lahan milik untuk proses sertifikasi tanaman pada areal dusung menghadapi perdagangan karbon di masa mendatang.

\section{DAFTAR PUSTAKA}

Asril. 2009. Pendugaan Cadangan Karbon Di Atas Permukaan Tanah Rawa Gambut Di Stasiun Penelitian Suaq balimbing Kabupaten Aceh Selatan Propinsi Nanggroe Aceh Darussalam. Program Pasca sarjana, Universitas Sumatera Utara.

Badan Standarisasi Nasional (BSN) : Standar Nasional Indonesia (SNI) 7724:2011, Pengukuran dan penghitungan cadangan karbon Pengukuran lapangan untuk penaksiran cadangan karbon hutan (ground based forest carbon accounting). 
Barchia, M.F. 2009. Evolusi Karbon Tanah. Program Pasca sarjana, Universitas Sumatera Utara. Artikel Surat Kabar Kompas Sabtu 13 Juni 2009, Dugaan cadangan karbon biomassa tumbuhan bawah dan serasah dikawasan suksesi alami pada area pengendapan tailing PT Freeport Indonesia.

Brown, S. 1997. Estimating biomass and biomass change of Tropical Forest: a Primer. Rome, Italy: FAO Forestry Paper 134.

Chairul, Erizal Muchktar, Mansyurdin, Tesri M, Gusmardi Indra, 2016. Struktur Kerapatan Vegetasi Dan Estimasi Kandungan Karbon Pada Beberapa Kondisi Hutan Di Pulau Siberut Sumatera Barat. Jurnal Metamorfosa III (1): 15-22 (2016).

Chave J. et al. 2005. Tree allometry and improved estimation of carbon stocks and balance in tropical forest. Oecologia 145:87-99.DOI $\quad 10.1007 / \mathrm{s} 00442$ 005-0100-x.

Hairiah K, Rahayu S. 2007. Petunjuk Praktis Pengkuran karbon tersimpan di berbagai macam penggunaan lahan. BOGOR. World agroforestry center - ICRAF, SEA Regional Office,University of Brawijaya, Unibraw, Indonesia. $77 \mathrm{p}$.

Hariadi Kartodihardjo, A Supriono, 2000. Dampak pembangunan sektoral terhadap konversi dan degradasi hutan alam: kasus pembangunan HTI dan perkebunan di Indonesia.

Heriyanto NM, Subiandono E. 2012. Komposisi dan struktur tegakan, biomasa, dan potensi kandungan karbon hutan mangrove di Taman Nasional Alas Purwo. Jurnal Penelitiandan Konservasi Alam. 9 (1) : 23 - 32.

Indriyanto. 2006.Ekologi Hutan. Buku. PT BumiAksara. Jakarta.210 p.

Kettering, Q. M., R. Coe, M. van Noordwijk, Y. Ambagau. C. A. Palm. 2001. Reducing uncertainty inthe use of allometric biomass equations for pre dicting above-ground tree biomass inmixed secondary forests.Forest Ecology and Management. Elsevier.

Martono, D. S. (2012). Analisis vegetasi dan asosiasi antara jenis-jenis pohon utama penyusun hutan tropis dataran rendah di Taman Nasional Gunung Rinjani Nusa Tenggara Barat. Jurnal Agri-Tek, 13(2).

Muhammad Abdul Munif Huse (2016) Implementasi Perdagangan Karbon Indonesia Jepang dalam Skemajoint Crediting Mechanism (JCM) 20132015 (Studi Kasus: PT. Primatexco Indonesia dan Ebara Refrigeration Equipment, Nippon Koei) eJournal Ilmu Hubungan Internasional, 2018, 6 (1) 251-264 ISSN 2477-2623 (online), ISSN 2477-2615 (print), ejournal.hi.fisip-unmul.ac.id Copyright 2016

Soerianegara I dan Indrawan A, 1983. Ekologi Hutan Indonesia. Institut Pertanian Bogor.

Suwardi, 2004. Teknologi Pengomposan Bahan Organik Sebagai Pilar Pertanian Organik. Simposium Nasional ISSAAS. Departemen Ilmu Tanah dan Sumberdaya Lahan, Fakultas Pertanian. IPB.

Tresnawan, H. and U. Rosalina. 2002. Estimating Above ground Biomass in the Primary and Logged-over Forest Ecosystem (Case Study Dusun Aro Forest, Jambi) (In Indonesian). Jurnal Manajemen Hutan Tropika 1 : $5-29$. 